\title{
Awareness and willingness to pay for cassava leaves as livestock feed ingredient among livestock farmers in Osun State
}

\section{Grace O. OLATUNDE*, Oluwafunmilola F. ADESIYAN}

Received: 04 $4^{\text {th }}$ December 2020 / Accepted: 04 ${ }^{\text {th }}$ August 2021

\begin{abstract}
Purpose: This study described the nutritional benefit of cassava leaf, assessed its level of cyanide content; examined respondents' awareness and perception; and analysed the factors determining livestock farmers' Willingness to Pay (WTP) for cassava leaves as a livestock feed ingredient.

Research Method: Multistage sampling method was employed to select 160 livestock farmers in Osun state and semi-structured interview method was used for data collection which were analysed using logistic regression model.

Findings: Results showed that larger percentages of the respondents are not aware of the nutritional benefit of the cassava leaf with $83 \%$ of the respondents willing to buy cassava leaves as feed. In addition, age, perception, business purpose, herd size, awareness and income seem to have an effect on farmers' WTP.
\end{abstract}

Research Limitation: Recommended safe cyanogen level in livestock feed has not been ascertained in literature; a knowledge gap for further research validation.

Originality/Value: Awareness, WTP and adoption of cassava leaf as a livestock feed ingredient could be made a generalized and sustainable economic development in animal feed sector if awareness could be increased.

Keywords: Awareness, Cassava leaf, Farmers, Livestock, Willingness to Pay (WTP)

\section{INTRODUCTION}

Cassava is cultivated as an annual crop in the tropical and sub-tropical regions for its edible starchy tuberous root as a major source of carbohydrate. Nigeria is the highest producer globally producing 57.1 million tones which is $21 \%$ out of the 277 million tones produced globally (FAOSTAT, 2016).

As reported by (FAO, 2002), importation of livestock feed ingredient especially the protein source e.g. soybean is becoming alarming so, also the research works on cassava in Thailand reveals that Thailand will be able to save 21 million US dollars by substituting $10 \%$ of soybeans with cassava leaves which in turn will reduce the importation of soybean as a livestock feed ingredient.

Literature findings revealed that cassava leaf contains a high crude protein of $16.7-39.9 \%$ dry weight comparable to that of fresh egg
(Ly and Angolan, 2007; Vasavi and Nirmala, 2016) with essential amino acid higher than soybean protein and with its overall vitamin level surpassing that of legumes, leafy legumes, milk, egg and cheese (Montagnac et al., 2009).

Various researchers have worked on cassava leaf fed to livestock (sheep, goat, pig, poultry, cattle and even fishes) and it has proved to increase their productivity in terms of milk yield, body weight gain and high palatability (Ngi et al., 2006; Marjurki et al., 2008; Olufemi et al., 2016; Diarra et al., 2017)

As useful as the leaves are, not so many of these livestock farmers are making use of it as feed probably because they are not aware of these nutritional benefits in cassava leaf and/ or because they do not seek for information OBAFEMI AWOLOWO UNIVERSITY

+23407031219009, +23408055439757

graceolatunde2015@gmail.com

iD https://orcid.org/0000-0003-0342-4653 
that could be of great benefit to them which could be a factor of their nature and status. In other words the characteristics of these farmers need to be established. With all these benefits in cassava leaf, there is also cyanide which could be very harmful if the level in cassava leaf is high (Montagnac et al., 2009; Islamiyat et al., 2016). This suggests the need to analyse the cyanide content in cassava leaf. Of great importance it will be, if cassava that usually gets wasted can be used as a livestock feed ingredient. Apart from it as a cheap source of feed to livestock farmers, it can serve as an income buffer to cassava farmers when the livestock farmers make use of it provided the users can pay for it. This necessitated the need to assess the willingness to pay for the cassava leaves. Since the way the users feel is of great importance which cannot be neglected, it also becomes expedient to assess the awareness, perception and the factors that will improve its use.

This study seeks to provide answers to the following questions. Who are the livestock farmers in the study area? Are livestock farmers really aware of nutritional benefits and the cyanide content in cassava leaf? What are livestock farmers' perceptions about cassava leaf as a livestock feed ingredient? If cassava leaf is to be produced and made available as livestock feed ingredient and marketed, will these livestock farmers be willing to pay for it? What are the determinants of their willingness to pay? The general objectives for this research work are to:

1.describe the nutritional benefit in cassava leaf and the socio-economic characteristics of the respondents in the study area;

2.assess the level of cyanide content in cassava leaf;

3.examine respondent's awareness and perception of cassava leaf as a livestock feed ingredient in the study area; and

4.analyse the factors determining livestock farmers' willingness to pay for cassava leaves.

Summarily, the pooled result from this study will be of great benefit to livestock farmers, cassava farmers, researchers, policy makers, businessmen, innovators/scientist and a relative impact on Nigerians as the country's economy will be improved. In a country like Nigeria that is leading globally in cassava production and still lacks the good things cassava leaf could achieve, thus, this study is proved to be necessary and relevant.

\section{MATERIALS AND METHODS}

\subsection{The study area}

The study was carried out in Osun state, an inland state in the south-western Nigeria, with its capital as Oshogbo. It has a total area cover of 9,251 square kilometers with a total population of $3,416,959$. Osun state lies between latitude $7^{\circ} 30 \mathrm{~N}$ and longitude $4^{\circ} 30 \mathrm{~N}$.

\subsection{Sampling technique}

Multistage sampling method was employed in this study for the selection of the respondents which are livestock farmers. At the first stage, purposive selection was adopted in selecting 2 livestock producing towns in Osun state which are Iwo and Ilesha. Random sampling was used to select 4 villages from each town and 20 livestock farmers were selected from each village which made a total of 160 respondents. Primary data will be used in this survey, thus, Semi -structured interview method will be used for this study.

\subsection{Analytical techniques}

Descriptive statistics such as tables, percentage, weighted mean and frequency were to describe the socioeconomic characteristics of livestock farmers, their awareness and perception about cassava leaf as a livestock feed ingredient. Contingent valuation method was used to evaluate willingness to pay and logistic regression model was used to analyse livestock farmers' willingness to pay for cassava leaves as a livestock feed ingredient with the use of Microsoft suite 2010 and STATA 14 package.

\subsubsection{Experimental assessment of cyanide in cassava leaf}

This was carried out at central laboratory of Federal University of Technology Akure 
(FUTA). The leaves of the cassava variety, TME-419 were harvested at 3month stage in the Obafemi Awolowo University Teaching and Research Farm (OAUT/R Farm), Ile-Ife and were divided into 2 parts labeled samples A and B. Methods used according to literatures reviewed in elimination of cyanide content in cassava leaves were adopted. According to (Lasmine et al., 2016) the new, fast and efficient method of total cyanide elimination which preserves a great concentration of B-carotene and omega-3-fatty acids is by heating at 75 degree Celsius for 33hours for $99.95 \%$ cyanide elimination; sample A was subjected to this condition using an electrical oven at agricultural engineering department, Obafemi Awolowo University, Ile-Ife and sample B was washed, chopped, wilted for 24 hours and sun dried for 36hours (Du Thanh and Preston, 2005). The two samples were grounded using the electrical mill and it was sieved, packaged in an air tight container and labeled for analysis in central Laboratory, FUTA. A weighed sample of cassava leaf powder (CLP) placed in a vial with known amount of buffer solution and Linamarase. A prepared yellow strip of filter paper was suspended and vial closed and whole content placed for 17hours in a 30 degree Celsius oven. There were colour changes from yellow to orange to brown of which was compared with the colour on a chart to obtain the amount of cyanogen present. This was obtained quantitatively by immersing the paper strip in water for 25 minutes and its absorbance against a blank, the absorbance was plotted against $\mathrm{HCN}$ content to confirm the amount of cyanide present. This was repeated for the two samples.

\subsubsection{Logistic regression model}

Willingness to pay is a dichotomous (binary) variable so, linear regression model will be used for the analysis of the willingness to pay of livestock farmers to pay for cassava leaves as a livestock feed ingredient because its asymptotic characteristics constrain the predicted probabilities to a range of zero to one. Also, the model is characterized by its mathematical simplicity and used where the dependent variable is binary. Logistic regression model as defined by the equation below:
$\mathrm{P}_{\mathrm{i}}=\mathrm{F}(\mathrm{Z})=\mathrm{F}\left(\alpha+\sum \beta_{i} X_{i}\right)=\frac{1}{1+e^{-Z}}$

Where: $\mathrm{P}_{i}$ is the probability that livestock farmers will be willing to buy cassava leaves as a livestock feed or not given the respondents $i^{\text {th }}$ explanatory variables; and $\alpha$ and $\beta$ are parameters to be estimated; and e represents the base of natural logarithms, which is approximately equal to 2.718 . The odds ratio of probability $\left(\mathrm{P}_{\mathrm{i}}\right)$ that an individual would choose an alternative to the probability $\left(1-\mathrm{P}_{\mathrm{i}}\right)$ that he/ she would not choose it:

$$
\frac{P i}{1-P i}=e^{z i}=e^{\left(\alpha+\sum \beta X i\right)}
$$

Applying logarithmic transformation to equation (5) gives the final equation:

$$
\mathrm{Zi}=\ln \left(\frac{P i}{1-P i}\right)=\alpha+\sum \beta \mathrm{iXi}
$$

If the disturbance term is introduced, the logit model becomes:

$$
Z i=\alpha+\sum \beta i X i+\mu i
$$

Where,

$\mathrm{i}=1,2,3 \ldots \mathrm{n}, \mathrm{n}$ is the number of explanatory variables, $\alpha \mathrm{i}$ is intercept, $\beta \mathrm{i}$ is logit parameters (slopes) of the equation in the model, $\mu \mathrm{i}=$ disturbance term, $\mathrm{Xi}=$ a vector of explanatory variables such as age, marital status, gender, education level, job type, family size, herd size, income, access to cassava leaves, distance, farm type, business purpose, management system, animal type, awareness, and perception and $\mathrm{Zi}$ is the explained variable.

\section{RESULTS AIV DISCUSSIONS}

\subsection{Nutritional Benefit of Cassava Leaf}

Table 1 reveals that cassava leaf is embedded with different types of amino acids, vitamins and minerals making it to be a relevant potential feed protein source or a feed supplement with other feed sources to reduce high cost of feed for livestock. 
Table 1: $\quad$ Result of nutritional benefit of cassava leaf

\begin{tabular}{|c|c|c|c|c|}
\hline $\begin{array}{l}\text { Proximate } \\
\text { composition } 100(g)\end{array}$ & Unit & $\begin{array}{l}\text { Raw } \\
\text { cassava }\end{array}$ & $\begin{array}{l}\text { Cassava } \\
\text { roots }\end{array}$ & $\begin{array}{l}\text { Cassava } \\
\text { leaves }\end{array}$ \\
\hline Food energy & Kcal & 160 & $110-149$ & 91 \\
\hline Food energy & KJ & 667 & $526-611$ & $209-251$ \\
\hline Moisture & $\mathrm{g}$ & 59.68 & $45.9-85.3$ & $64.8-88.6$ \\
\hline Dry weight & $\mathrm{g}$ & 40.32 & $29.8-39.3$ & $19-28.3$ \\
\hline Protein & $\mathrm{g}$ & 1.36 & $0.3-3.5$ & $1.0-10.0$ \\
\hline Lipid & $\mathrm{g}$ & 0.28 & $0.03-0.5$ & $0.2-2.9$ \\
\hline Total carbonhydrate & $\mathrm{g}$ & 39.06 & $25.3-35.7$ & $7-18.3$ \\
\hline Dietary fiber & g & 1.8 & $0.1-3.7$ & $0.5-10.0$ \\
\hline Ash & $\mathrm{g}$ & 0.62 & $0.4-1.7$ & $0.7-4.5$ \\
\hline \multicolumn{5}{|l|}{ Vitamins } \\
\hline Thiamin & $\mathrm{mg}$ & 0.087 & $0.03-0.28$ & $0.06-0.31$ \\
\hline Riboflavin & $\mathrm{mg}$ & 0.048 & $0.03-0.06$ & $0.021-0.74$ \\
\hline Niacin & $\mathrm{mg}$ & 0.854 & $0.6-1.09$ & $1.3-2.8$ \\
\hline Ascorbic acid & $\mathrm{mg}$ & 20.6 & $14.9-50$ & $60-370$ \\
\hline Vitamin A & $\mu \mathrm{g}$ & $*$ & $5.0-35.0$ & $8300-11800^{*}$ \\
\hline \multicolumn{5}{|l|}{ Minerals } \\
\hline Calcium & $\mathrm{mg}$ & 16 & $19-176$ & $34-708$ \\
\hline Total phosphorus & $\mathrm{mg}$ & 27 & $6-152$ & $27-211$ \\
\hline $\mathrm{Ca} / \mathrm{P}$ & & 0.6 & $1.6-5.48$ & 2.5 \\
\hline Iron & $\mathrm{mg}$ & 0.27 & $0.3-14.0$ & $0.4-8.3$ \\
\hline Potassium & $\%$ & $*$ & $0.25-0.72$ & $0.35-1.23$ \\
\hline Magnesium & $\%$ & $*$ & $0.03-0.08$ & $0.12-0.42$ \\
\hline Copper & ppm & $*$ & $2.00-6.00$ & $3.00-12.0$ \\
\hline Zinc & ppm & $*$ & $14.00-41.00$ & $71.00-249.0$ \\
\hline Sodium & ppm & $*$ & $76.00-213.00$ & $51.0-177.0$ \\
\hline Manganese & ppm & $*$ & $3.00-10.00$ & $72.0-252.0$ \\
\hline Amino acid profile & $\begin{array}{l}\text { \%on } \\
16 \mathrm{gN}\end{array}$ & $\begin{array}{l}\text { Egg } \\
\text { protein }\end{array}$ & $\begin{array}{l}\text { Cassava } \\
\text { leaf }\end{array}$ & $\begin{array}{l}\text { Cassava } \\
\text { root }\end{array}$ \\
\hline Tryptophan & & 1.5 & 1.5 & - \\
\hline Threonine & & 4.9 & 2.8 & 4.7 \\
\hline Isoleucine & & 8.0 & 5.0 & 1.8 \\
\hline Leucine & & 9.2 & 8.9 & 2.9 \\
\hline Lysine & & 3.9 & 7.2 & 7.2 \\
\hline Methionine & & 4.1 & 1.7 & 1.0 \\
\hline Cysteine & & 2.4 & 1.4 & - \\
\hline phenylalanine & & 6.3 & 5.8 & 2.1 \\
\hline Tyrosine & & 4.5 & 4.2 & 1.6 \\
\hline Valine & & 7.3 & 5.8 & 2.6 \\
\hline Arginine & & 6.4 & 5.3 & 14.9 \\
\hline Histidine & & 2.1 & 2.2 & 1.7 \\
\hline
\end{tabular}

Source: Montagnac et al., 2009 


\subsection{Socio-Economic Characteristics of the Respondents}

Table 2 shows that $52 \%$ of respondents interviewed are of average age of 41 years. Maritally, a higher percentage, $79 \%$ of the respondents interviewed are married while $15 \%$ of the respondents are single. $56 \%$ of the respondents are male while $44 \%$ of the respondents interviewed are female which implies the business is dominated by both genders. $35 \%$ of respondents are educated to primary level of education, 35\% attained secondary level, $17 \%$ attained tertiary level and $13 \%$ were not educated formally.

Results show that $87 \%$ of the respondents are literates that can write, read to an extent and could interprete the implications of some of their decisions. $85.6 \%$ of respondents operate small scale businesses while $14.3 \%$ of them operate medium scale group and none involved in large scale business. $4.3 \%$ have an income within the range of $0-50$ naira, $5 \%$ within the range of $51-100$ naira, $73.7 \%$ in the range of $101-500$ naira, $11.2 \%$ in the range of 501-1000 naira and $9 \%$ having over 1000 naira on their animal per day. The socio-economic characteristics of the respondents also agree with reviewed literatures (Pato, 2013 and Tolulope et al., 2018).

\subsection{Level of Cyanide Content in Cassava Leaf}

Analysis carried out on cassava leaf revealed that it contains $22.29 \mathrm{mg} / \mathrm{L}$ of cyanide for both samples A and B as shown in Figure 01 . Cassava peels have been the major feed given to livestock in the study area (according to Table 3), cassava peels contain $200 \mathrm{mg} / \mathrm{L}$ of hydrocyanide according to (FAO, 1991). If animals could consume up to this level of hydrocyanide content in cassava peels, then the content of hydrocyanide in cassava leaf analysed above is either quite low or livestock farmers have subjected their animals to a high level of cyanogenic glucoside consumption. Several health organizations including WHO have inconclusive views about the acceptable level of cyanide content in food that can be consumed. Notwithstanding, (Okafor et al., 2003), in his clarification on cyanide content in livestock feed concluded that a level of cyanogen below $50 \mathrm{mg} \mathrm{HCN} / \mathrm{kg}$ should be the target for cassava-based livestock ration.

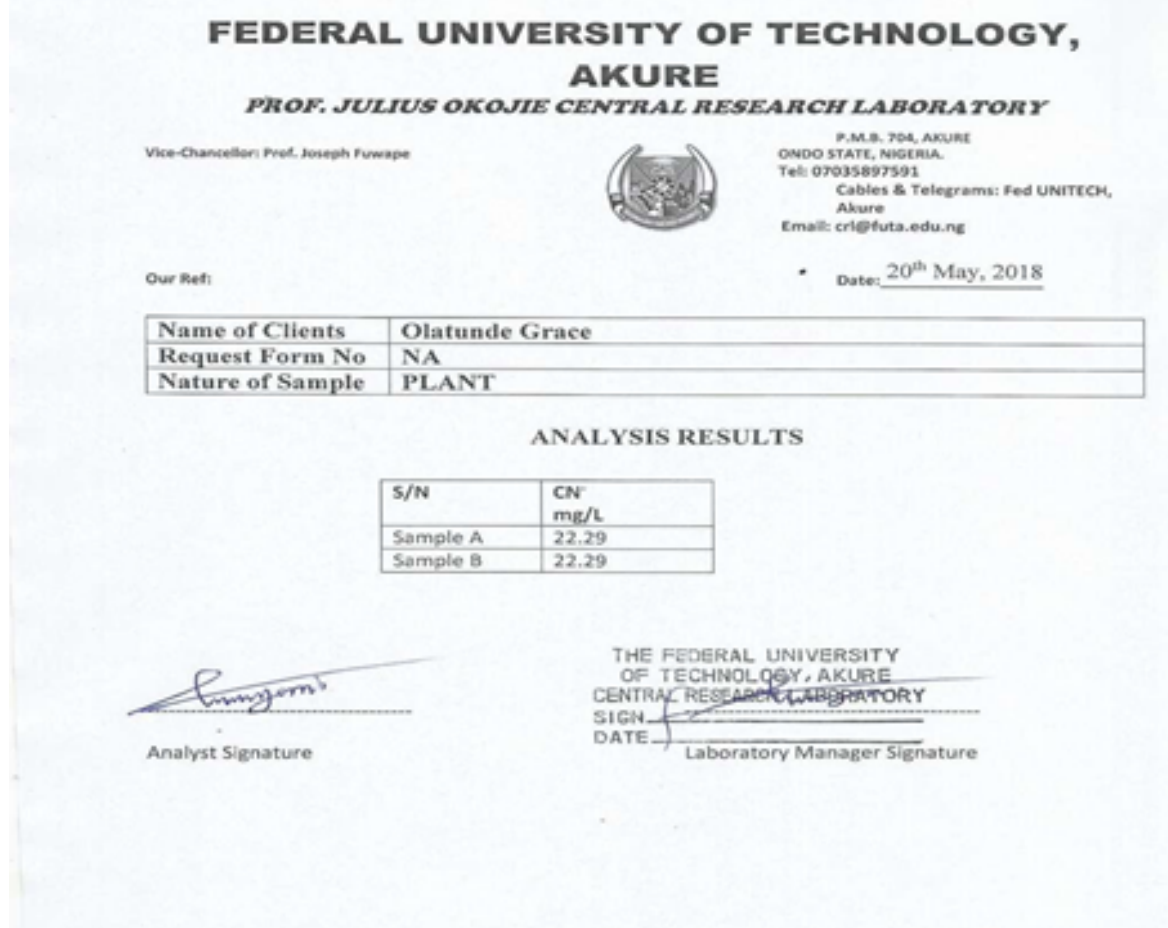

FIGURE 1: Showing analysis result of cyanide content in cassava leaf 
Table 2: $\quad$ Socio economic characteristics of respondents in years

\begin{tabular}{|c|c|c|}
\hline AGE (IN YEARS) & Frequency & percentage \\
\hline $20-30$ & 36 & 23 \\
\hline $31-40$ & 41 & 26 \\
\hline $41-50$ & 42 & 26 \\
\hline Above 50 & 41 & 26 \\
\hline Total & 160 & 100 \\
\hline Mean age & 42.54 & \\
\hline \multicolumn{3}{|l|}{ MARITAL STATUS } \\
\hline Single & 24 & 15 \\
\hline Married & 126 & 79 \\
\hline Widow & 6 & 4 \\
\hline Divorced & 4 & 3 \\
\hline Others & 0 & 0 \\
\hline Total & 160 & 100 \\
\hline \multicolumn{3}{|l|}{ GENDER } \\
\hline Male & 89 & 56 \\
\hline Female & 71 & 44 \\
\hline Total & 160 & 100 \\
\hline \multicolumn{3}{|c|}{ LEVEL OF EDUCATION } \\
\hline Primary & 56 & 35 \\
\hline Secondary & 56 & 35 \\
\hline Tertiary & 27 & 17 \\
\hline Adult education & 0 & 0 \\
\hline None & 21 & 13 \\
\hline Total & 160 & 100 \\
\hline \multicolumn{3}{|l|}{ BUSINESS SIZE } \\
\hline Small & 137 & 85.6 \\
\hline Medium & 23 & 14.3 \\
\hline Large & 0 & 0 \\
\hline Total & 160 & 100 \\
\hline \multicolumn{3}{|l|}{ INCOME(NAIRA) } \\
\hline $0-100$ & 15 & 9.3 \\
\hline $101-500$ & 118 & 73.7 \\
\hline $501-1000$ & 18 & 11.2 \\
\hline Over 1000 & 9 & 5.6 \\
\hline Total & 160 & 100 \\
\hline
\end{tabular}

Source: Field Survey, 2018. 


\subsection{Awareness Level of the Respondents about Cassava Leaf}

Table 3 below shows the level of awareness of the respondents about the nutrients, antinutritional factor in cassava leaf. A higher percentage of the respondents are not aware of the nutrients embedded and none of them are also aware of the hydrocyanide content of cassava leaf. Since minimal numbers of respondents are aware of cassava leaf usage as a feed, this implies the usage of cassava leaf as a feed is not generally known by livestock farmers. It can be deduced from the table that cassava peels are a major feed ingredient used in feeding livestock in the study area

3.5. Perception of the Respondents about Cassava Leaf

Table 4 below shows the perception of the respondents. $45 \%$ of them reported that they were ignorant of the benefits in cassava leaf beforehand, $28.7 \%$ reported that they must have to see others adopting the usage of cassava leaf as a livestock feed or feed ingredient before they can use it, $0.6 \%$ said cassava leaf affected animals, possibly carrying the bitter variety notion of past ages with them. 5.6\% of the respondents complained that they made such a decision because cassava leaf could not be sufficient for animals as feed per say. $6.2 \%$ decided they could not use it due to reasons personally known to them of which were not stated and $3.1 \%$ reported that it was good for animals as they had tried it before and they would still continue using it due to good results seen. $4.3 \%$ of these respondents stated that cassava leaf was only good for traditional animals, that their foreign animals were always given foreign feed to eat and any local feed given to them, affected them and consequently led to their death.

Table 3: $\quad$ Awareness level of respondents

\begin{tabular}{lll}
\hline Awareness level & Frequency & percentage \\
\hline what do you feed your animal with? & 119 & 74.3 \\
Cassava peels \& some other peels & & 20.6 \\
PKC, GNC e.t.c & 33 & 5.0 \\
Hays and other grasses & 8 & $\mathbf{1 0 0}$ \\
Total & $\mathbf{1 6 0}$ & \\
\hline Do you know cassava leaf is high in nutrient than & & 23.7 \\
some conventional feed? & & 76.2 \\
\hline Yes & 38 & $\mathbf{1 0 0}$ \\
No & 122 & \\
Total & $\mathbf{1 6 0}$ & 1.2 \\
\hline Are you aware? & & 98.7 \\
\hline Yes & 2 & $\mathbf{1 0 0}$ \\
No & 158 & \\
Total & $\mathbf{1 6 0}$ & \\
\hline
\end{tabular}

Source: Field Survey, 2018. 
Table 4: $\quad$ Perception about cassava leaf as livestock feed

\begin{tabular}{lrl}
\hline Reason & Frequency & percentage \\
\hline Ignorance & 72 & 45.0 \\
Others must use it first & 46 & 28.7 \\
It affects animal & 1 & 0.6 \\
It can't be sufficient for animals & 9 & 5.6 \\
I can't use it & 10 & 6.2 \\
It is good for animals & 5 & 3.1 \\
Only good for traditional animals & 7 & 4.3 \\
Total & $\mathbf{1 6 0}$ & $\mathbf{1 0 0}$ \\
\hline
\end{tabular}

Source: Field Survey, 2018.

Table 5: Willingness to pay for cassava leaf as livestock feed

\begin{tabular}{lll}
\hline $\begin{array}{l}\text { If cassava leaf is made for sale in your area as } \\
\text { live-stock feed, will you buy it? }\end{array}$ & Frequency & percentage \\
\hline Yes & 133 & 83.1 \\
No & 27 & 16.9 \\
Total & $\mathbf{1 6 0}$ & $\mathbf{1 0 0}$ \\
\hline
\end{tabular}

\begin{tabular}{lll}
\hline $\begin{array}{l}\text { How much Will you buy 3kg of fresh cassava } \\
\text { leaf? (\#) }\end{array}$ & & \\
\hline $0-10$ & 44 & 27.5 \\
$11-50$ & 68 & 42.5 \\
$51-100$ & 24 & 15.0 \\
$101-150$ & 2 & 1.2 \\
$151-200$ & 11 & 6.8 \\
$201-500$ & 9 & 5.6 \\
$501-1000$ & 2 & 1.2 \\
Over 1000 & 0 & 0 \\
Total & $\mathbf{1 6 0}$ & $\mathbf{1 0 0}$ \\
\hline Mean price & $\# \mathbf{1 0 1 . 4 7}$ & \\
\hline
\end{tabular}




\subsection{Willingness to Pay of the Respondents for Cassava Leaf as Livestock Feed Ingredient.}

Table 5 below shows the reply of the respondents to the question that if cassava leaf is made available for sale in your area, will you buy it and how much they will buy; $3 \mathrm{~kg}$ fresh cassava leaf? A higher number of the respondents replied "Yes" accounting for $83 \%$ of the total respondents while $16.9 \%$ said they could not buy cassava leaf as a livestock feed ingredient due to the number of reasons given by these group of people and were willing to buy at a mean price of \#101.47. This shows that having being enlightened about the benefits in cassava leaf, these respondents are willing to buy it if available to them.

\subsection{Factors Affecting Willingness to Pay of the Respondents for Cassava Leaf as a Livestock Feed Ingredient.}

Table 6 below shows the result of the analysis of WTP using the logistic regression model. The pseudo R2 has a value of $59.4 \%$ which implies that $59.4 \%$ of the variations in WTP are explained by the model and the log likelihood has a value of -28.82 which is low and thus the model is very fit. From Table 06, awareness; age, perception, business purpose, herd size and income are the only significant variables while other variables which are marital status, gender, education level, job type, family size, access to cassava leaves, the distance to cassava source, farm type, management system and animal type are not significant which is in agreement with past literatures reviewed (Dilek et al., 2010; Mathieu et al., 2018 and Tolulope et al., 2018). Awareness is significant at a $1 \%$ level; age, perception, business purpose and herd size at a $5 \%$ level and income at a $10 \%$ level. Awareness, herd size and income have a positive relationship with WTP; the higher these variables become, the more willing the respondents will be to pay for cassava leaves. Also, Age, perception and business purpose have a negative correlation with WTP and thus, the higher these variables become, the WTP for cassava leaves by the respondents declines.

Table 7 below shows the marginal effect of each of the variables on WTP as a post estimation after the logistic regression has been carried 521 out so as to view the effect of an additional unit or percentage of a variable on the WTP as estimated by the derivatives of the WTP to the corresponding derivative of the attribute of interest. Just as seen above and the result from the logistic regression that income, age, herd size, business purpose, awareness and perception are the significant variables affecting WTP. Age, income, business purpose and perception have a negative marginal effect of $-0.00321,-0.0000198,-0.15136$ and -0.228727 respectively which implies that when any of these variables increases by one percent, then, the mean WTP is likely to decrease by $0.321 \%$, $0.0019 \%, 15.13 \%$ and $22.87 \%$ respectively. Also, herd size and awareness have a positive marginal effect of 0.0015684 and 0.2463891 respectively which implies that when any of the two variables increases by one percent, then, the mean WTP is likely to increase by $0.156 \%$ and $24.63 \%$ respectively.

Summarily, this study reveals that cassava leaf contains relatively a high amino acid, vitamins, minerals and cyanogen level which is considerably low with respect to reviewed literatures (Okafor et al., 2003). The study was able to answer all its research questions but it's limited to ascertain safe cyanogen level in livestock feed. Notwithstanding, cassava peels which is a dominant feed ingredient in the study area was reported to have a higher cyanide level within the range of $253-1081 \mathrm{mg} / \mathrm{kg}$ (FAO, 1991; Tweyongyere and Katongole, 2002). This reveals cassava leaf stands the chance of a potential livestock protein source or supplement with other feed sources as concluded by Oresegun et al., (2016) after further read watch validation.

Livestock farming business in the study area is flooded with men and women having some level of education and operating on small scale business majorly with a proportionate income level whose socio-economic characteristics reveal they can only ascribe a good value and are willing to pay for feed they are well aware about, generally used by other farmers and reported to be effective as shown in their perception about cassava leaves as a feed and the analysed factors affecting their willingness to pay. 
Table 6: Showing the result of logistic regression

\begin{tabular}{lllll}
\hline WTP & Coef. & Std. Error & $\mathbf{Z}$ & $\mathbf{P}>|\mathbf{Z}|$ \\
\hline Age & -.0600175 & .030214 & -1.99 & $0.047^{* *}$ \\
Marital status & -1.173915 & 1.131218 & -1.04 & 0.299 \\
Gender & .8527448 & .8771044 & 0.97 & 0.331 \\
Education level & -.4196107 & .3100463 & -1.35 & 0.176 \\
Job type & .3042619 & .8966958 & 0.34 & 0.734 \\
Family size & .0323051 & .1343187 & 0.24 & 0.810 \\
Herd size & .0293226 & .0117556 & 2.49 & $0.013^{* *}$ \\
Income & -.000371 & .0001991 & -1.86 & $0.062^{* * *}$ \\
Access & .331776 & 1.06575 & 0.31 & 0.756 \\
Distance & .0861029 & .1168379 & 0.74 & 0.461 \\
Farm type & .2623151 & 1.174384 & 0.22 & 0.823 \\
Business purpose & -2.829873 & 1.204035 & -2.35 & $0.019^{* *}$ \\
Management system & .199798 & .380424 & 0.53 & 0.599 \\
Animal type & -.0166215 & .3461744 & -0.05 & 0.962 \\
Awareness & 4.606433 & 1.196342 & 3.85 & $0.000^{*}$ \\
Perception & -.4276225 & .1851526 & -2.31 & $0.021^{* *}$ \\
Constant & 9.805402 & 4.035817 & 2.43 & $0.015^{* *}$ \\
\hline & $c h i 2(16)=84.36$ & & \\
\hline
\end{tabular}

${ }^{1}$ Number of observation $=160$, LR chi2 $(16)=84.36$, Prob $>$ chi $2=0.0000$

Log likelihood $=-28.828204$, Pseudo $R 2=0.5940$

* indicates significance at 1\%, ** indicates significance at 5\%, *** indicates significance at $10 \%$

Source: field work 
Table 7: $\quad$ Showing Average marginal effect of the variables on WTP

\begin{tabular}{|c|c|c|c|c|}
\hline Variables & $d y / d x$ & Std. Error & $\mathbf{Z}$ & $\mathbf{P}>|\mathbf{Z}|$ \\
\hline Age & -.0032102 & .0015425 & -2.08 & $0.037 * *$ \\
\hline Marital status & -.0627904 & .0596648 & -1.05 & 0.293 \\
\hline Gender & .0456116 & .0462094 & 0.99 & 0.324 \\
\hline Education level & -.0224442 & .0157482 & -1.43 & 0.154 \\
\hline Job type & .0162744 & .0478066 & 0.34 & 0.734 \\
\hline Family size & .0017279 & .007192 & 0.24 & 0.810 \\
\hline Herd size & .0015684 & .0005734 & 2.74 & $0.006^{*}$ \\
\hline Income & -.0000198 & .0000102 & -1.94 & $0.053 * * *$ \\
\hline Access & .017746 & .0567757 & 0.31 & 0.755 \\
\hline Distance & .0046055 & .0062299 & 0.74 & 0.460 \\
\hline Farm type & .0140307 & .0628847 & 0.22 & 0.823 \\
\hline Business purpose & -.1513643 & .0606238 & -2.50 & $0.013 * *$ \\
\hline Management system & .0106868 & .0202629 & 0.53 & 0.598 \\
\hline Animal type & -.0008891 & .0185215 & -0.05 & 0.962 \\
\hline Awareness & .2463891 & .0532911 & 4.62 & $0.000^{*}$ \\
\hline Perception & -.0228727 & .0092831 & -2.46 & $0.014 * *$ \\
\hline
\end{tabular}

${ }^{2}$ Number of observation $=160$, Expression: $\operatorname{Pr}($ Buy), dy/dx w.r.t. : Age, Mstatus, Gender, Educ.lev, Jobtype, famlysize, Herdsize, Income, Access, Distance, Farmtype, Purpose, Mgtsyt, Animaltype Awareness Perception. * indicates significance at 1\%, ** indicates significance at 5\%, *** indicates significance at $10 \%$ Source: field work 


\section{CONCLUSIONS AND REFERENCES}

\subsection{Conclusions}

It was concluded from this study that cassava leaves have the potential to serve as a good source of livestock feed and can also serve as a good substitute or supplement for protein source in livestock feed.

Livestock farmers in the study area are generally not aware of the nutrients, cyanide content and its use as a livestock feed ingredient. The study found out that age, perception, business purpose, herd size, awareness and income are the factors that influence willingness to pay of livestock farmers for cassava leaves as a livestock feed ingredient. In conclusion, these farmers are willing to buy and use cassava leaves after being made aware of their nutritional benefits.

\subsection{Recommendations}

It is recommended that strategies such as conferences, extension programs should be implemented by the government so as to increase the awareness and thus, promote the use of cassava leaves among livestock farmers as a livestock feed ingredient in the study area and that adequate trainings through extension agents are needed for livestock farmers to educate them on the preparation and use of cassava leaves as a feed for animals. It is recommended that cassava leaf must be introduced to feed millers after which, research has been conducted on the best, safe and economical ways and proportion to have cassava leaves milled into different forms and also incorporated into formulated meals/ diets of different livestock to meet their various demands.

\section{References}

Dilek, B.B., Fuat, B., Ozlem, O.K. (2010). Livestock producers' needs and willingness to pay for extension services in Adana Province of Turkey. African Journal of Agricultural Research. 5(110, pp1187-1190. DOI: 10.5897/AJAR09.567

Du Thanh and Preston. (2005). The effects of simple processing methods of cassava leaves in HCN content and intake by growing pigs. Livestock Research for Rural Development. 17(9). URL: http://www.irrd.org/irrd17/9/hang17099.htm

FAO. (1991). The FAO expert consultation on Roots, Tubers, Plantains and Banana in Animal Feeding held in Columbia at Centro International de Agricultural Tropical (CIAT), $21^{\text {st }}-25^{\text {th }}$ of January, 1991.[Available online]: www.fao.org/3/T0554E/T0554E06.htm.Accessed on: $28 / 2 / 2019$

FAO Expert Consultation and Workshop on protein sources for the animal feed industry in Bangkok, Thailand. $29^{\text {th }}$ of April-3 ${ }^{\text {rd }}$ of May, 2002. [Available online]: www.fao.org/docrep/007/y5019e/ y5019e03.htm.Accessed on: 24/12/2018.FAOSTAT. (2016).[Available online]: www.factfish.com/statistic-country/Nigeria/cassava,+production+quantity.

Islamiyat, F.B., Moruf, O.O., Sulaiman, A.O. and Adeladun, S.A.(2016) A review of cyanogenic glycosides in edible plants. Toxicology-New aspects to this scientific conundrum. URL: https://www.intechopen.com/books/toxicology-newconundrum/a-review-of-cyanogenicglycosides-in-edible-plants.

Lasmine, G.P., Julianna, M.V., Denis, F.M., Gleice, R.S.A., Jesui, V.V., Swami, A.M. and Oscar, O.S.J. (2016). Easy methods of removal of cyanogens from cassava leaves with retention of vitamins and Omega-3 fatty acids. Journal of Brazilian Chemical Society. https://dx.doi. org/105935/0103-5053.20160027

Ly, N.T.H., Ngoan, L.D.,Verstegen, M.W.A., and Hendriks, W.H. (2012). Pig performance increases 
with the addition of d1-methionine and 1-lysine to ensiled cassava leaf protein diets. Tropical Animal Health and production. 44(1), 165-172. DOI: 10.1007/s11250-011-9904-3.

Marjurki, H.E., Sulistyo, D.W., Rini, I., Artharini, I., Soebarinoto and Howeler, R. (2008). The use of cassava leaf sillage as a feed supplement in diets for ruminants and its introduction to small holders farmers. Livestock Research for Rural Development. 20(6).https://hdl.handle. net/10568/44184

Mathieu, O., Silamana, B., Robert, B.Z., Samuel, T.P., Leopold, S. and Gregoire, B. (2018). Farmers' Willingness to pay for Climate information Services: Evidence from Cowpea and Sesame producers in Northern Burkina Faso. Sustainability. 2018, 10(3), 611.http://doi.org/10.3390/ su10030611

Montagnac, J.A., Christopher, R.D. and Sherry, A.T. (2009). Nutritional value of cassava for use as a staple food and recent advances for improvement. Comprehensive Reviews in Food Science and Food Safety. 8(3). https://doi.org/10.1111/j.1541-4337.2009.00077.x

Ngi, J., Ayoade, J.A. and Oluremi, O.I.A. 2006. Evaluation of dried cassava leaf meal and maize offal as supplements for goats fed rice straws in dry season. Livestock Research for Rural Development. 18(9). https://www.irrd.cipav.org.co/irrd18/9/ngi18127.htm

Okafor, P.N. and Nwabuko, C.U. (2003). Cyanide, nitrates and nitrite contents of livestock feeds in Umuahia, Nigeria. Biokemistri. 14:57-63. URL: http://www.bioline.org.br/pdf

Olufemi, S.A., Amos, O.F., Adeniyi, J.A., Andreas, S. and Eva, S. (2016). Feed value of Enzyme Suplemented Cassava leaf meal and shrimp meal in pigs. Bulletin of Animal Health and Production in Africa. 64(1).https://www.ajol.info/index.php/bahpa/article/view/150410

Oresegun, A., Fagbenro, O.A., Ilona, P., and Edah, B. (2016). Nutritional and anti-nutritional composition of cassava leaf protein concentrate from six cassava varieties for use in aqua feed. Cogent Food \& Agriculture. 2(1). DOI: https://doi.org/10.1080/23311932.2016.1147323

Pato Innocensia D. (2013). Assessment of consumer acceptance and willingness to pay for induced quality attributes in processed cassava leaves product in Morogoro municipality. Sokoine University of Agriculture. URI: http://hdl.handle.net/123456789/536

Soaks, S.D., Malakai, K., Simeli, T., Latu, M., Sila, I., Jiaoti, B., Tevita, V., Vasenai,R., and Ulusagogo, L. (2017). Evaluation of cassava leaf meal protein in fish and soybean mealbased diets for young pigs. Journal of Agriculture and Rural Development in the Tropics and Subtropics. Vol.118(1), 105-112 URL: https://core.ac.uk/download/pdf/84263558.pdf

Tolulope, J.A., Gbenga, J.O. and Kasali, A. (2018). An analysis of willingness to pay (WTP) for improved water supply in Owo local government, Ondo state, Nigeria. Asian Research Journal of Arts and Social Sciences. 5(3):1-15. https://doi.org/10.9734/arjass/2018/39282

Tweyongyere, R. and Katongole, I. (2002). Cyanogenic potential of cassava peels and their detoxification for utilization as livestock feed. Veterinary and Human Toxicology. 44(6):3669 URL: https//europepmc.org/article/med/12458644

Vasavi, R.K. and Nirmala N. (2016). Cassava: meeting the global protein need. Plant science today. 3(3): 304-311. http://dx.doi.org/10.14719/pst.2016.3.3.249 